\title{
STOSOWANIE ŚRODKÓW KONTROLI I NADZORU NAD PRZESTRZEGANIEM PRZEPISÓW I ZASAD OCHRONY PRACY W PRAKTYCE INSPEKTORÓW PRACY
}

\begin{abstract}
Abstrakt: Niniejszy artykuł jest próbą przedstawienia problemów państwowych inspektorów pracy, z jakimi spotykają się w praktyce kontroli i nadzoru. Wzrost zadań Państwowej Inspekcji Pracy, przy jednoczesnym rozwoju stopnia i intensywności stosunków społeczno-gospodarczych, wpływa na pojawienie się wielu nowych wątpliwości w przedmiocie prowadzonych postępowań kontrolnych, a także nadzorczych. Celem rozprawy jest zaakcentowanie kilku istotnych zagadnień związanych z postępowaniem kontrolno-nadzorczym państwowego inspektora pracy. Analizie poddano zarówno przebieg kontroli, jak i środki prawne stosowane przez inspektora pracy.
\end{abstract}

Słowa kluczowe: Państwowa Inspekcja Pracy, kontrola, nadzór

\section{WSTĘP}

Stulecie istnienia Państwowej Inspekcji Pracy jest doskonałą okazją do podsumowań $i$ analiz rozwiązań prawnych stosowanych w tak długim okresie. Niezmiennie od wielu lat zasadniczą funkcją urzędu jest kontrola i nad zór nad warunkami pracy, co zostało wprost wyeksplikowane w art. 1 ustawy z dnia 13 kwietnia 2007 roku o Państwowej Inspekcji Pracy․․ Jakkolwiek te dwa cele wciąż są aktualne, to jednak ich dzisiejszy charakter prawny podlega istotnym przeobrażeniom. Należy podkreślić, że Państwowa Inspekcja Pracy jest organem powołanym do sprawowania nadzoru i kontroli przestrzegania prawa pracy, w szczególności przepisów i zasad bezpieczeństwa i higieny pracy, a także przepisów dotyczących legalności zatrudnienia i innej pracy zarobkowej w zakresie określonym w ustawie. Jak zauważa Krzysztof W. Baran ${ }^{2}$, zakres kompetencji Państwowej Inspekcji Pracy jest stosunkowo rozległy, obejmuje nie tylko role kontroli i nadzoru. Ujmując zagadnienie całościowo, kompetencje można podzielić następująco:

1 Ustawa z dnia 13 kwietnia 2007 roku o Państwowej Inspekcji Pracy, tekst jedn. Dz.U. z 2018 r. poz. 623 z późn. zm. (dalej: ustawa o PIP).

2 K.W. Baran, [w:] Kodeks pracy. Komentarz, red. K.W. Baran, Warszawa 2012, s. 149 n. 
1. kontrolno-nadzorcze,

2. prewencyjno-informacyjne,

3. opiniodawczo-doradcze,

4. szkoleniowe,

5. procesowe,

6. śledcze,

7. orzecznicze.

Według Mirosława Włodarczyka w polskim porządku prawnym inspekcja pracy oznacza grupę podmiotów powołanych przez państwo do pełnienia zarówno kontroli, jak i nadzoru nad przestrzeganiem prawa pracy, a główny ciężar realizowania tych zadań powierzono organom jednostek administracji publicznej, zaopatrzonych w profesjonalne narzędzia nadzorczo-kontrolne ${ }^{3}$. Dlatego też za celowe uznać należy szczególne zwrócenie uwagi na ten właśnie obszar aktywności Państwowej Inspekcji Pracy. Zgodnie z przepisami ustawy o PIP jej organami są: Główny Inspektor Pracy, okręgowi inspektorzy pracy, a także inspektorzy pracy, którzy działają, co do zasady, w ramach terytorialnej właściwości okręgowych inspektoratów pracy. Zgodnie zaś z art. 22 ust. 1 ustawy o PIP kontrole przeprowadzają inspektorzy pracy i to właśnie te organy w praktyce stosują środki prawne z dziedziny kontroli i nadzoru nad warunkami pracy, które co do zasady zostały szczegółowo wskazane w art. 11 ustawy o PIP.

Państwowi inspektorzy pracy są uprawnieni do dokonywania zarówno kontroli, jak i nadzoru - przesądza o tym wprost przytoczony art. 1 ustawy o PIP. Jak wskazuje Dariusz Makowski ${ }^{4}$, art. 1 ustawy o PIP wyodrębnia pojęcia kontroli i nadzoru, co należy uznać za uprawnione, albowiem zadania państwowych inspektorów pracy mogą ograniczać się niekiedy jedynie do funkcji kontrolnej, bez środków nadzoru, a to oznacza wyłączenie funkcji nadzorczej w ujęciu administracyjnoprawnym. Bardzo często jednak organy Państwowej Inspekcji Pracy dysponują rozbudowanym instrumentarium o charakterze władczym, które wpływa na działalność podmiotu kontrolowanego; wówczas przyjmuje się realizowanie funkcji nadzorczej przez państwowego inspektora pracy. Zasadne jest zaakcentowanie, że państwowi inspektorzy pracy działają zarówno w dziedzinie kontroli, jak i nadzoru ${ }^{5}$ - i to będzie przedmiotem niniejszego artykułu.

${ }^{3}$ M. Liwo, Problematyka ryzyka zawodowego w stosunkach pracy i stosunkach stużbowych oraz egzekwowanie jego oceny przez Państwowa Inspekcję Pracy. Studia z zakresu prawa i polityki społecznej, Sosnowiec 2018, s. 337 n.

${ }^{4}$ D. Makowski, Inspekcja pracy jako instytucja państwowego nadzoru nad przestrzeganiem prawa pracy, Łódź 2017, s. $180 \mathrm{n}$.

5 Tak też J. Jagielski, [w:] M. Gersdorf, J. Jagielski, K. Rączka, Komentarz do ustawy o Państwowej Inspekcji Pracy, Warszawa 2008, s. 18. 


\section{KONTROLA I NADZÓR}

Celem precyzyjnego odniesienia do tematu konieczne jest zauważenie, że w nauce prawa administracyjnego pojęcie kontroli rozumiane jest jako proces obejmujący: 1. badanie zgodności stanu istniejącego ze stanem postulowanym, 2. ustalenie zasięgu i przyczyn rozbieżności, 3. przekazanie wyników tego ustalenia, a czasem i wynikających stąd dyspozycji, podmiotowi kontrolowanemu i podmiotowi organizacyjnie zwierzchniemu ${ }^{6}$. Nieco inaczej jest definiowany nadzór. Zdaniem Jana Bocia ${ }^{7} \mathrm{~W}$ nauce prawa administracyjnego kontrola sprawowana przez organ zwierzchni organizacyjnie nad kontrolowanym, a zatem i odpowiedzialny za jego działania, w przypadku wyposażenia tego organu zwierzchniego w środki oddziaływania władczego wobec podrzędnego w strukturze podmiotu kontrolowanego, jest kontrolą o charakterze kwalifikowanym, to jest właśnie na z zorem. Należy jednak przyjąć, że mimo niewystępowania podporządkowania w postaci wzajemnej nadrzędności organizacyjnej w rozumieniu administracyjnoprawnym nadal nadzór sprawowany przez organy Państwowej Inspekcji Pracy ma charakter nadzoru w rozumieniu prawa administracyjnego, a wyraża się w kompetencjach władczego oddziaływania na sferę działalności podmiotu kontrolowanego. Działaniom nadzorczym towarzyszy również sankcja egzekucyjna, wyrażająca się możliwością przymuszenia podmiotu kontrolowanego do nakazanego zachowania $\mathrm{w}$ postaci na przykład postępowania egzekucyjnego $\mathrm{w}$ administracji celem zapewnienia wykonania decyzji administracyjnej.

W rozumieniu codziennego postępowania państwowego inspektora pracy kontrola oznacza ustalenie stanu faktycznego w przedmiocie objętym zadaniami i kompetencjami państwowego inspektora pracy. Stanowisko to potwierdza art. 21 ustawy o PIP, zgodnie z którym postępowanie kontrolne ma na celu ustalenie stanu faktycznego w zakresie przestrzegania prawa pracy, w szczególności przepisów i zasad bezpieczeństwa i higieny pracy, a także przepisów dotyczących legalności zatrudnienia, oraz udokumentowanie dokonanych ustaleń. Tadeusz Zieliński i Grzegorz Goździewicz czynności inspekcyjne państwowych inspektorów pracy dzielą na dwie kategorie: kontrolne sensu stricto oraz rozstrzygające konkretne sprawy w formie nakazów czy sprzeciwów ${ }^{8}$.

W związku z tym, że środki kontroli i nadzoru mogą być rozumiane zarówno jako środki służące przeprowadzeniu kontroli, jak i środki stosowane po zakończeniu postępowania kontrolnego w reakcji na stwierdzone naruszenia przypadki naruszenia prawa, obie kategorie będą tworzyły podstawę niniejszego referatu.

6 J. Boć, Prawo administracyjne, Wrocław 1998, s. 346.

7 Ibidem, s. 351.

8 T. Zieliński, G. Goździewicz, [w:] Kodeks pracy. Komentarz, red. L. Florek, Warszawa 2017, s. 176. 


\section{ŚRODKI POSTĘPOWANIA KONTROLNEGO}

Rozdział czwarty ustawy o PIP szczegółowo określa procedurę postępowania kontrolnego, a art. 23 szczegółowo określa uprawnienia państwowego inspektora pracy w toku postępowania kontrolnego.

Niezwykle istotnym problemem praktycznym jest ustalanie przypadków, w których postępowanie kontrolne może być w ogóle prowadzone. O ile zakres przedmiotowy można stosunkowo łatwo ustalić, o tyle zakres podmiotowy stwarza pewne wątpliwości. Należy podkreślić, że co do zasady organy Państwowej Inspekcji Pracy są uprawnione do kontrolowania podmiotów enumeratywnie wymienionych w art. 13 ustawy o PIP:

1. pracodawców - a w zakresie bezpieczeństwa i higieny pracy oraz kontroli legalności zatrudnienia także niebędących pracodawcami przedsiębiorców i innych jednostek organizacyjnych — na których rzecz jest świadczona praca przez osoby fizyczne, w tym przez osoby wykonujące na własny rachunek działalność gospodarczą, bez względu na podstawę świadczenia tej pracy;

2. podmiotów świadczących usługi pośrednictwa pracy, doradztwa personalnego, poradnictwa zawodowego oraz pracy tymczasowej w rozumieniu art. 18 ust. 1 ustawy z dnia 20 kwietnia 2004 roku o promocji zatrudnienia i instytucjach rynku pracy - w zakresie przestrzegania obowiązków, o których mowa w art. 10 ust. 1 pkt 3 lit. d i e;

3. podmiotów, o których mowa w art. 18c ustawy z dnia 20 kwietnia 2004 roku o promocji zatrudnienia i instytucjach rynku pracy - w zakresie przestrzegania warunków określonych w art. 19c, art. 19d, art. 19fa, art. 19ga, art. 85 ust. 2 $i$ art. 85a tej ustawy;

3a) przedsiębiorców, do których stosuje się przepisy ustawy z dnia 10 stycznia 2018 roku o ograniczeniu handlu w niedziele i święta oraz w niektóre inne dni ${ }^{10}$;

4. pracodawców delegujących pracowników na terytorium RP w zakresie określonym w ustawie z dnia 10 czerwca 2016 roku o delegowaniu pracowników w ramach świadczenia usług ${ }^{11}$;

5. przedsiębiorców albo innych jednostek organizacyjnych, na których rzecz w ramach prowadzonej przez te podmioty działalności jest wykonywane zlecenie lub są świadczone usługi przez przyjmującego zlecenie lub świadczącego usługi w zakresie wypłacania takim osobom wynagrodzenia w wysokości wynikającej z wysokości minimalnej stawki godzinowej, zgodnie z przepisami ustawy z dnia

9 Ustawa z dnia 20 kwietnia 2004 roku o promocji zatrudnienia i instytucjach rynku pracy, tekst jedn. Dz.U. z 2019 r. poz. 1482.

${ }^{10}$ Ustawa z dnia 10 stycznia 2018 roku o ograniczeniu handlu w niedzielę i święta oraz w niektóre inne dni, tekst jedn. Dz.U. z 2019 r. poz. 466.

11 Ustawa z dnia 10 czerwca 2016 roku o delegowaniu pracowników w ramach świadczenia usług, tekst jedn. Dz.U. z 2018 r. poz. 2206. 
10 października 2002 roku o minimalnym wynagrodzeniu za pracę ${ }^{12}$ — zwanych dalej ,podmiotami kontrolowanymi”.

Lektura przytoczonego przepisu wyraźnie wskazuje, że są pewne podmioty, które nie będą podlegały kontroli państwowego inspektora pracy — można do nich zaliczyć osobę fizyczną lub spółkę, która nie powierza pracy osobom fizycznym. Wówczas taki podmiot nie jest objęty zakresem podmiotowym kontroli PIP, gdyż art. 13 nie wymienia takiej kategorii podmiotów jako podlegających kontroli PIP. Problemem jest jednak, w jaki formalny sposób organ kontroli PIP ma dokonać takiego ustalenia. Czy wystarczy oświadczenie osoby uprawnionej do reprezentowania podmiotu? Czy należy dokonać w takim przypadku wezwania do złożenia wyjaśnień na okoliczność próby podjęcia kontroli? Uprawnienia kontrolne państwowego inspektora pracy znajdują zastosowanie w postępowaniu kontrolnym, a to może dotyczyć wyłącznie podmiotów, które podlegają kontroli. Aktualnie nie ma wyraźnej podstawy prawnej odnośnie do działania państwowego inspektora pracy, oczekującego złożenia odpowiednich wyjaśnień na tę okoliczność przez osobę fizyczną reprezentującą podmiot kontrolowany, który nie podlega kontroli PIP. Można zauważyć, że gwoli prawidłowości prowadzenia postępowania kontrolnego istnieje potrzeba rozważenia w prowadzenia instytucji postępowania przedkontrolnego, którego celem byłoby zweryfikowanie możliwości prowadzenia postępowania kontrolnego i nadzorczego wobec danego podmiotu.

Innym problemem nieuregulowanym w ustawie, a coraz częściej spotykanym, jest zagadnienie kontroli kilku podmiotów, które pozostają we wzajemnych relacjach gospodarczych, a ustalenia w przedmiocie stanu faktycznego są niezbędne odnośnie do prawidłowości dalej podejmowanych działań. Doskonałym przykładem takich złożoności są kontrole prowadzone w agencjach pracy tymczasowej, zatrudniających pracowników tymczasowych, a następnie kierujących ich do pracy u pracodawców użytkowników. Niekiedy konieczne jest przeprowadzenie kontroli w obu tych podmiotach jednocześnie, udokumentowanie stanu faktycznego w odrębnych protokołach i zastosowanie środków prawnych przewidzianych ustawą. Zagadnieniem istotnym praktycznie jest jednak możliwość wykorzystania $\mathrm{w}$ protokole sporządzonym $\mathrm{z}$ kontroli $\mathrm{w}$ agencji pracy tymczasowej ustaleń dokonanych u pracodawcy użytkownika lub odwrotnie. Podobne problemy dotyczą grup kapitałowych lub innych podmiotów powiązanych gospodarczo. Możliwość wykorzystania ustaleń dokonanych podczas jednej kontroli w toku kontroli przeprowadzanej $\mathrm{w}$ innym podmiocie kontrolowanym jest nieuregulowana prawnie, a niekiedy staje się wręcz niezbędna dla całościowego ujęcia sprawy.

Podobnym problemem pozostaje kwestia braku instytucji tak zwanej pomocy prawnej realizowanej w ramach działań PIP. Nierzadko postępowania kontrolne

12 Ustawa z dnia 10 października 2002 roku o minimalnym wynagrodzeniu za pracę, tekst jedn. Dz.U. z 2018 r. poz. 2177 z późn. zm. 
dotyczą podmiotów o ogólnokrajowym zakresie działania i funkcjonowania, na przykład banków, agencji pracy tymczasowej, urzędów centralnych, korporacji itp. Inspektorzy pracy jako organy kontrolne działają w ramach swojej właściwości rzeczowej, lecz także miejscowej, to jest najczęściej na obszarze danego województwa. Przeprowadzając kontrolę na terenie danego województwa w siedzibie danego podmiotu, na przykład we Wrocławiu, państwowy inspektor pracy może podjąć decyzję, że konieczne jest dokonanie ustaleń w jednostce organizacyjnej pracodawcy poza obszarem województwa, w którym działa, to jest poza województwem dolnośląskim, na przykład w Warszawie. Jeśli nie zostanie upoważniony do przeprowadzenia czynności kontrolnych poza ustawowym obszarem działania, to jest poza województwem dolnośląskim przez Głównego Inspektora Pracy, wówczas prawnie nie ma takiej możliwości. Konieczne jest wtedy przeprowadzenie postępowania kontrolnego przez państwowego inspektora pracy z OIP w Warszawie. Mimo dokonania takich ustaleń rodzi się jednak wątpliwość, czy ustalenia zawarte w odrębnym protokole kontroli mogą zostać wykorzystane w innym postępowaniu kontrolnym jako element postępowania kontrolnego. Wydaje się naturalne, że takie rozwiązanie prawne powinno być dostępne i stosowane wprost ze względów praktycznych, jednak względy natury proceduralnej wymagają uregulowania takiej instytucji w przepisach ustrojowych Państwowej Inspekcji Pracy rangi ustawowej.

Innym ciekawym zagadnieniem jest kwestia tajemnicy przedsiębiorstwa jako element postępowania kontrolnego. Ustawodawca wprowadził w art. 31 ust. 2 pkt 14 ustawy o PIP jako element postępowania kontrolnego na wniosek podmiotu kontrolowanego wzmiankę o informacjach objętych tajemnicą przedsiębiorstwa. Obecna konstrukcja przepisu wprowadza normę prawną obligującą w istocie państwowego inspektora pracy do odnotowania w protokole kontroli na skutek zawnioskowania przez przedsiębiorcę informacji o tajemnicy przedsiębiorstwa. Państwowy inspektor pracy nie został jednak przepisem kompetencyjnym upoważniony do odmowy przyjęcia przedmiotowego wniosku. Takie uprawnienie powinno zostać przydane w przepisach rangi ustawy, jednak jeśli nie ma takiej regulacji, to w razie złożenia takiego wniosku przez podmiot kontrolowany powstaje wiele wątpliwości. Zasadnicze pytanie dotyczy możliwości odrzucenia takiego wniosku przez państwowego inspektora pracy. Redakcja przepisu wyklucza taką możliwość. Kolejną wątpliwością jest, czy na podstawie przepisów ustawy o PIP państwowy inspektor pracy może weryfikować treść złożonego wniosku przez pracodawcę i wymagać jego uzupełnienia lub doszczegółowienia. Na to pytanie także nie ma odpowiedzi. Zauważyć jednak należy kwestię i jednocześnie pytanie, czy państwowy inspektor pracy jest w ogóle kompetentny prawnie i merytorycznie do oceny, czy treść protokołu ma charakter tajemnicy przedsiębiorstwa, czy też nie. Również w tej odpowiedzi konieczne są regulacje ustawowe ze względu na wzrastający stopień skomplikowania zachodzących stosunków społeczno-gospodarczych. 


\section{ŚRODKI KONTROLNE I NADZORCZE}

Prezentując zagadnienie środków kontroli i nadzoru w praktyce państwowych inspektorów pracy, należy podkreślić, że zasadnicze normy kompetencyjne zostały zawarte w art. 11 ustawy o PIP i normy prawne tego przepisu staną się kanwą dalszych rozważań.

Zgodnie ze wskazanym przepisem w razie stwierdzenia naruszenia przepisów prawa pracy lub przepisów dotyczących legalności zatrudnienia właściwe organy Państwowej Inspekcji Pracy są uprawnione odpowiednio do:

1. nakazania usunięcia stwierdzonych uchybień w ustalonym terminie, jeśli naruszenie dotyczy przepisów i zasad bezpieczeństwa i higieny pracy;

2. nakazania: wstrzymania prac lub działalności, gdy naruszenie powoduje bezpośrednie zagrożenie życia lub zdrowia pracowników lub innych osób wykonujących te prace lub prowadzących działalność; skierowania do innych prac pracowników lub innych osób dopuszczonych do pracy wbrew obowiązującym przepisom przy pracach wzbronionych, szkodliwych lub niebezpiecznych albo pracowników lub innych osób dopuszczonych do pracy przy pracach niebezpiecznych, jeżeli pracownicy ci lub osoby nie mają odpowiednich kwalifikacji; nakazy w tych sprawach podlegają natychmiastowemu wykonaniu;

3. nakazania wstrzymania eksploatacji maszyn i urządzeń, jeśli ich eksploatacja powoduje bezpośrednie zagrożenie życia lub zdrowia ludzi; nakazy w tych sprawach podlegają natychmiastowemu wykonaniu;

4. zakazania wykonywania pracy lub prowadzenia działalności w miejscach, w których stan warunków pracy bezpośrednio zagraża życiu lub zdrowiu ludzi; nakazy w tych sprawach podlegają natychmiastowemu wykonaniu;

5. nakazania, w wypadku stwierdzenia, że stan bezpieczeństwa i higieny pracy zagraża życiu lub zdrowiu pracowników lub osób fizycznych wykonujących pracę na innej podstawie niż stosunek pracy, w tym osób wykonujących na własny rachunek działalność gospodarczą, zaprzestania prowadzenia działalności bądź działalności określonego rodzaju;

6. nakazania ustalenia, w określonym terminie, okoliczności i przyczyn wypadku;

6a. nakazania wykonania badań i pomiarów czynników szkodliwych i uciążliwych w środowisku pracy w wypadku naruszenia trybu, metod, rodzaju lub częstotliwości wykonania tych badań i pomiarów lub konieczności stwierdzenia wykonywania pracy w szczególnych warunkach;

7. nakazania pracodawcy wypłaty należnego wynagrodzenia za pracę, a także innego świadczenia przysługującego pracownikowi; nakazy w tych sprawach podlegają natychmiastowemu wykonaniu;

8. skierowania wystąpienia lub wydania polecenia, w razie stwierdzenia innych naruszeń niż wymienione w pkt 1-7, w sprawie ich usunięcia, a także wyciągnięcia konsekwencji w stosunku do osób winnych. 
Przepis ten dotyczy dwu zasadniczych rodzajów środków prawnych stosowanych przez państwowych inspektorów pracy w związku z realizowaniem funkcji kontrolno-nadzorczych. Nakazy i zakazy, przybierające postać decyzji administracyjnej i jako środki władcze są immanentnie związane z zadaniami nadzorczymi PIP, oraz wystąpienia i polecenia, które są środkami niewładczymi i świadczą o realizowaniu przez państwowego inspektora pracy funkcji kontrolnej i stanowią tak zwane działania naprawcze.

\section{ŚRODKI NADZORU}

Środki prawne formułowane w postaci nakazów i zakazów, będące decyzjami administracyjnymi państwowego inspektora pracy, poza jednym wyjątkiem - nakazem płatniczym, o którym mowa w art. 11 pkt 7 ustawy o PIP — ukierunkowane są na regulowanie nieprawidłowości w dziedzinie bezpieczeństwa i higieny pracy. Podkreślić należy, że decyzje mogą być skierowane zarówno do pracodawcy, to jest podmiotu kontrolowanego zatrudniającego pracowników, jak i do podmiotu niebędącego pracodawcą, lecz powierzającego pracę osobom fizycznym na innej podstawie niż stosunek pracy, na przykład na podstawie umowy zlecenia lub umowy o dzieło.

Prezentowane rozwiązania, w których państwowy inspektor pracy jest uprawniony do władczego oddziaływania w dziedzinie bezpieczeństwa i higieny pracy, są w swojej istocie rozwinięciem norm konstytucyjnych wyrażonych w art. 66 ust. 1 Konstytucji Rzeczypospolitej Polskiej ${ }^{13}$, zgodnie z którymi każdy ma prawo do bezpiecznych i higienicznych warunków pracy, a sposób realizacji tego prawa oraz obowiązki pracodawcy określa ustawa.

Państwowy inspektor pracy w sposób władczy ingeruje w przypadku naruszenia przepisów o ochronie pracy w dziedzinie bhp, wówczas gdy dotyczy ono pracowników, ale też osób świadczących pracę na innej podstawie. Istotnym problemem praktycznym jest tu jednak konstrukcja prawna gwarancji bezpiecznych i higienicznych warunków pracy w stosunku do osób wykonujących pracę na innej podstawie niż stosunek pracy na rzecz przedsiębiorców i pracodawców. Doniosłość problemu praktycznego, lecz także jurydycznego, bardzo trafnie ujął Michał Raczkowski ${ }^{14}$, wskazując, że polski prawodawca zbyt ogólnie formułuje obowiązki z zakresu bhp, jakie powinny być dopełnione przez pracodawców lub przedsiębiorców wobec osób świadczących pracę na innej podstawie niż stosunek pracy. Stan taki wywołuje niepewność co zakresu obowiązków podmiotów zatrudniających, albowiem jakkolwiek podlegają one kontroli i nadzorowi Państwowej

13 Dz.U. z 1997 r. Nr 78, poz. 78, ze sprost. i zm.

14 M. Raczkowski, Bezpieczne i higieniczne warunki pracy w zatrudnieniu cywilnoprawnym, „Praca i Zabezpieczenie Społeczne” 2019, nr 1, s. 70. 
Inspekcji Pracy, to jednak szczegółowy zakres obowiązków nie jest jednoznaczny. Wynika to z niefortunnego, jak się wydaje, sformułowania brzmienia art. 304 ustawy z dnia 26 czerwca 1974 roku Kodeks pracy ${ }^{15}$. Zgodnie ze wskazanym przepisem pracodawca jest obowiązany zapewnić bezpieczne i higieniczne warunki pracy, o których mowa w art. 207 § 2 k.p., osobom fizycznym wykonującym pracę na innej podstawie niż stosunek pracy w zakładzie pracy lub w miejscu wyznaczonym przez pracodawcę, a także osobom prowadzącym w zakładzie pracy lub w miejscu wyznaczonym przez pracodawcę na własny rachunek działalność gospodarczą. Dodatkowo zgodnie z $§ 2$ pracodawca jest obowiązany zapewnić bezpieczne i higieniczne warunki zajęć odbywanych na terenie zakładu pracy przez studentów i uczniów niebędących jego pracownikami. Szczególne brzmienie ma natomiast $§ 3$ artykułu, zgodnie z którym obowiązki określone w art. 207 $\S 2$ k.p. stosuje się odpowiednio do przedsiębiorców niebędących pracodawcami, organizujących pracę wykonywaną przez osoby fizyczne: 1. na innej podstawie niż stosunek pracy; 2. prowadzące na własny rachunek działalność gospodarczą. Dodatkowo w razie prowadzenia prac w miejscu, do którego mają dostęp osoby niebiorące udziału w procesie pracy, pracodawca jest obowiązany zastosować środki niezbędne do zapewnienia ochrony życia i zdrowia tym osobom. Wskazany artykuł osobno odnosi się do pracodawców, a osobno do przedsiębiorców jako podmiotów zobowiązanych do zapewnienia bezpiecznych i higienicznych warunków pracy. Ustawodawca, nakładając realizację owego obowiązku na pracodawcę, nie dokonał ukonkretnienia, lecz odsyła do brzmienia art. 207 § 2 k.p., który jest bardzo ogólnym przepisem i ma niezwykle szeroki zakres przedmiotowy. Przypomnijmy, że zgodnie z nim pracodawca jest obowiązany chronić zdrowie i życie pracowników przez zapewnienie bezpiecznych i higienicznych warunków pracy przy odpowiednim wykorzystaniu osiągnięć nauki i techniki. W szczególności pracodawca jest obowiązany:

1. organizować pracę w sposób zapewniający bezpieczne i higieniczne warunki pracy;

2. zapewniać przestrzeganie w zakładzie pracy przepisów oraz zasad bezpieczeństwa i higieny pracy, wydawać polecenia usunięcia uchybień w tym zakresie oraz kontrolować wykonanie tych poleceń;

3. reagować na potrzeby w zakresie zapewnienia bezpieczeństwa i higieny pracy oraz dostosowywać środki podejmowane w celu doskonalenia istniejącego poziomu ochrony zdrowia i życia pracowników, biorąc pod uwagę zmieniające się warunki wykonywania pracy;

4. zapewnić rozwój spójnej polityki zapobiegającej wypadkom przy pracy i chorobom zawodowym uwzględniającej zagadnienia techniczne, organizację pracy, warunki pracy, stosunki społeczne oraz wpływ czynników środowiska pracy;

15 Ustawa z dnia 26 czerwca 1974 roku Kodeks pracy, tekst jedn. Dz.U. z 2019 r. poz. 1040 z późn. zm. (dalej: k.p.). 
5. uwzględniać ochronę zdrowia młodocianych, pracownic w ciąży lub karmiących dziecko piersią oraz pracowników niepełnosprawnych w ramach podejmowanych działań profilaktycznych;

6. zapewniać wykonanie nakazów, wystąpień, decyzji i zarządzeń wydawanych przez organy nadzoru nad warunkami pracy;

7. zapewniać wykonanie zaleceń społecznego inspektora pracy.

Zasadniczym problemem jest zakres stosowania tego przepisu w stosunku do osób świadczących pracę na innej podstawie niż stosunek pracy. Przyjęcie, że ma być on stosowany w całości do osób świadczących pracę na podstawie umów cywilnoprawnych, jak to się dzieje w stosunku do pracowników, rodzi wówczas uzasadnione wątpliwości, dlaczego prawodawca ochronę bhp dla niepracowników wskazał dopiero w art. 304 k.p., a nie odniósł tego przez nakazanie stosowania całego działu dziesiątego k.p. zarówno wobec pracowników, jak i niepracowników. Ale też nie ma skonkretyzowanego zakresu przedmiotowego obowiązków bhp wobec osób świadczących pracę na innej podstawie niż stosunek pracy, co rodzi problemy w stosowaniu prawa przez państwowych inspektorów pracy. Organy administracji publicznej są zobowiązane do działania na podstawie prawa i w granicach prawa. W wypadku tak ogólnego sformułowania zawartego w art. 304 k.p. działania państwowego inspektora pracy mogą napotykać problemy związane z praktycznym stosowaniem tego przepisu, ze względu na jego nieprecyzyjność. Jednocześnie należy przypomnieć, że norma konstytucyjna wyrażona wprost w art. 66 ust. 1 Konstytucji Rzeczypospolitej Polskiej, postanawiająca o prawie do bezpiecznych i higienicznych warunków pracy, gwarantuje to prawo każdemu — zarówno pracownikowi, jak i niepracownikowi ${ }^{16}$. W takim przypadku realizacja funkcji nadzorczej państwowego inspektora pracy jest wielce utrudniona, ze względu na brak konkretnej normy prawnej określającej zakres obowiązków podmiotu kontrolowanego, który mógłby być następnie przedmiotem nakazu. Jednocześnie w tej części rozważań warto za Arkadiuszem Sobczykiem podnieść, że problem definiowania pracownika w rozumieniu przepisów Konstytucji powinien być szerszy od pojęcia pracownika rozumianego w prawie pracy, co autor określa mianem deficytu aktualnej regulacji prawa pracy w zakresie definiowania pracownika ${ }^{17}$.

Kolejnym środkiem oddziaływania władczego państwowego inspektora pracy jest tak zwany nakaz płatniczy regulowany art. 11 pkt 7 ustawy o PIP. Przedmiotem tejże decyzji administracyjnej jest nakazanie pracodawcy wypłaty należnego wynagrodzenia za pracę, a także innego świadczenia przysługującego pracownikowi. Należy przypomnieć, że nakazy w tych sprawach podlegają natychmiastowemu wykonaniu. W przeciwieństwie do nakazów o których była mowa, nakaz płatniczy może być skierowany wyłącznie do pracodawcy, czyli podmiotu zatrudniającego pracowników, natomiast nie może być skierowany do podmiotu który

16 Tak też B. Banaszak, Konstytucja RP. Komentarz, Warszawa 2009, s. 342 n.

17 A. Sobczyk, Wolność pracy i władza, Warszawa 2015, s. 272 n. 
pracodawcą nie był lub utracił status pracodawcy (na przykład zwolnił ostatniego zatrudnianego pracownika). Istotne jest poczynienie uwagi, że przedmiotowy nakaz, podobnie jak poprzednie, ma charakter deklaratoryjny, a nie konstytutywny, a jego zadaniem jest niejako wymuszenie na pracodawcy wypełnienia obowiązku wynikającego z zawartej z pracownikiem umowy. Można użyć często spotykanego w literaturze sformułowania o „przypominaniu” pracodawcy ciążących na nim obowiązków ustawowych wskazanych w art. 80 i 94 pkt 5 k.p. Ważną kwestią w pracy państwowych inspektorów jest przesłanka niezbędna do wydania nakazu płatniczego i sposób jej rozumienia, a mianowicie „należność” wynagrodzenia za pracę czy też świadczenie ,przysługujące” pracownikowi ${ }^{18}$. W praktyce państwowych inspektorów pracy, wobec utrwalonej linii orzeczniczej, lecz także poglądów wyrażanych w literaturze, można dostrzec mocne akcentowanie aspektu bezsporności świadczenia i przewartościowanie literalnego brzmienia przepisu mówiącego o „należności” czy „przysługiwaniu” na rzecz „bezsporności”, co czyni nakaz płatniczy mniej efektywnym. Problem ten nabrał istotnego znaczenia.

Jak słusznie zauważa Olgierd Kucharski ${ }^{19}$, najbardziej doniosłym czynnikiem, którego zaistnienie warunkuje możliwość wydania nakazu płatniczego, jest wykazanie przez państwowego inspektora pracy „należności” wynagrodzenia za pracę. Autor podnosi, że pojęcie „należnego wynagrodzenia” ma w istocie charakter obiektywny i jest niezależne od oceny inspektora pracy. W praktyce oznacza to, że prawo do wynagrodzenia nie może budzić wątpliwości lub być przedmiotem sporu między pracodawcą a pracownikiem. W toku postępowania kontrolnego wykazanie owej należności czy wręcz bezsporności świadczenia może odbywać się w rozmaity sposób. W praktyce kontrolnej państwowego inspektora pracy cel ten jest osiągany przez naliczenie przedmiotowych świadczeń przez pracodawcę na imiennej karcie wynagrodzeń, a następnie zatwierdzenie do wypłaty jako należnego świadczenia przysługującego pracownikowi. Owa należność świadczenia i bezsporność jest wykazywana w toku kontroli złożenia przez pracodawcę oświadczenia o tym, że dane świadczenie uznaje za mające takie właśnie cechy, to jest należne i bezsporne. Niekiedy oświadczenie to jest uzupełniane o sformułowanie, że niewypłacenie wynagrodzenia jest następstwem braku środków finansowych, co dodatkowo wskazuje, że to świadczenie jest należne pracownikowi, a nie reguluje się go wyłącznie dlatego, że brakuje środków finansowych. Wykazanie należności wynagrodzenia za pracę może być też osiągnięte przez wskazanie, że prawo do niego wynika wprost z przepisów prawa. Zaakcentować należy jednak, że istotnym problemem jest kwestionowanie owej należności czy bezsporności przez pracodawcę $\mathrm{w}$ toku postępowania kontrolnego i wykazywanie różnych okoliczności podważających zasadność wypłacenia pracownikowi wynagrodzenia za pracę.

18 Zagadnienie to sygnalizuje między innymi M. Nowak, Wynagrodzenie za pracę, Warszawa 2014, s. $180 \mathrm{n}$.

19 O. Kucharski, Nakazy płacowe inspektora pracy — geneza i skutki, „Przegląd Prawa Publicznego" 2017, nr 7-8, s. 169-175. 
Pracodawcy często podnoszą, że praca nie została wykonana w sposób prawidłowy, pracownik nie przepracował całego czasu pracy, wykonana praca ma wady jakościowe lub nieodpowiada należytej staranności, jaka powinna być zachowana podczas jej wykonywania.

Konieczne jest wskazanie, że państwowy inspektor pracy jest zobowiązany do szczegółowego ustalenia należności wynagrodzenia za pracę, to jest nie tylko wysokości świadczenia, lecz także tytułu prawnego (wynagrodzenie za pracę, wynagrodzenie za pracę w godzinach nadliczbowych, dodatki z tytułu pracy w godzinach nadliczbowych ze wskazaniem ich rodzajów, wynagrodzenia za czas urlopu wypoczynkowego, ekwiwalentu pieniężnego z tytułu niewykorzystanego urlopu wypoczynkowego itp.), jak też okresu, za który dane świadczenie przysługuje. Obowiązek dokonania takich drobiazgowych ustaleń jest zrozumiały i bardzo dobitnie został podkreślony w wyroku Naczelnego Sądu Administracyjnego $\mathrm{z}$ dnia 4 stycznia $2010 \mathrm{roku}^{20}$. W prezentowanym judykacie podniesiono kilka istotnych aspektów, które mają doniosły walor praktyczny. W uzasadnieniu NSA podniósł, że ów nakaz płatniczy może być wydany wyłącznie wówczas, gdy obowiązek pracodawcy jest bezsporny i wymagalny już w momencie przeprowadzenia kontroli. Jak zauważono dalej, państwowy inspektor pracy może nakazać wypłatę należnego wynagrodzenia za pracę lub innego świadczenia, wówczas gdy należność ta jest wyliczona, jej wysokość i podstawa są bezsporne, a ponadto nie budzi jakiejkolwiek wątpliwości fakt niewypłacenia owej należności. Wskazano na sformułowanie „należne wynagrodzenie”, które w ocenie składu orzekającego ma charakter obiektywny — i co szczególnie istotne — niezależny od przekonania samego inspektora pracy. Naczelny Sąd Administracyjny zaprezentował nawet przykłady takich sytuacji i wymienił niezaistnienie sporu między pracownikiem a pracodawcą co do świadczenia, przypadek gdy wynagrodzenie jest obliczone i zatwierdzone przez pracodawcę względnie gdy wymagalność wynagrodzenia stwierdzona jest prawomocnym wyrokiem sądu. Szczególnie istotna jest konstatacja NSA, wedle której nie można mówić o „należnym wynagrodzeniu” w rozumieniu przepisu, jeżeli takiego stanowiska nie podziela pracodawca. Również przesłanka „należnego wynagrodzenia” nie jest w ocenie NSA spełniona, jeżeli wykładnia przepisów prawa pracy mających zastosowanie przy dokonywaniu takiej oceny i kwalifikacji skutków prawnych określonych czynności prawnych może być różna. Przedstawiona linia orzecznicza jest stosunkowo konsekwentna, co potwierdza wcześniejszy wyrok Naczelnego Sądu Administracyjnego z dnia 13 lipca $2006 \mathrm{roku}^{21}$. Stanowisko to znajduje potwierdzenie w orzecznictwie sądów administracyjnych. W przedmiotowym orzeczeniu zaprezentowano pogląd, wedle którego ideą nakazu wypłaty wynagrodzenia jest nakłonienie pracodawcy do wypełnienia ciążącego na nim obowiązku wobec pracownika, lecz tylko wówczas

20 Sygn. akt I OSK 791/09, http://orzeczenia.nsa.gov.pl/doc/B18F99E019.

21 Sygn. akt I OSK 1400/05, LEX 2754465. 
gdy obowiązek ten jest wymagalny. W przypadku zaistnienia sporu o roszczenie ze stosunku pracy inspektor nie ma prawnej możliwości nałożenia obowiązku wypłaty należnego pracownikowi wynagrodzenia. Tomasz Niedziński zauważa ${ }^{22}$, że państwowy inspektor pracy może odstąpić od wydania nakazu płatniczego, gdy pracownik wystąpił z roszczeniem o wynagrodzenie do sądu lub pracodawca wystąpił do sądu o prawidłowe ustalenia wynagrodzenia za pracę względnie gdy przedmiotem sporu jest wysokość świadczenia. Istotna jest też uwaga autora, wedle której państwowy inspektor pracy nie może posłużyć się w takim przypadku wystąpieniem — niewładczą formą działania państwowego inspektora pracy. Niedziński uzasadnia swoją tezę stanowiskiem, wedle którego lektura art. 11 pkt 7 i 8 ustawy o PIP wskazuje, że inspektor pracy nie ma prawa wyboru stosowania środków prawnych przewidzianych ustawą.

Wydaje się, że mocne akcentowanie, a niekiedy wręcz absolutyzowanie przesłanki „należnego wynagrodzenia” w wypadku nakazów płatniczych istotnie zmniejsza skuteczność działań państwowych inspektorów pracy. W praktyce pojęcie należności ustąpiło bowiem pojęciu bezsporności, a jak się wydaje, są to dwa odmienne wyrazy, o nieco innym desygnacie znaczeniowym.

Rozważenia wymaga, czy akcentowanie „należności” świadczenia, a wręcz przewartościowanie tego pojęcia na rzecz „,bezsporności” nie pozostaje w związku z wątpliwościami, jakie towarzyszyły wprowadzeniu instytucji nakazu płatniczego w 2001 roku $^{23}$. Doktryna formułuje poglądy, zgodnie z którymi nakaz płatniczy jest ingerencją organu administracji publicznej za pomocą instrumentu publicznoprawnego w dziedzinę prywatnoprawną zastrzeżoną dla kompetencji sądów powszechnych. Tezę taką wyraził między innymi Jacek Skoczyński ${ }^{24}$, podnosząc, że niewypłacenie przysługującego pracownikowi wynagrodzenia należy do kategorii spraw o charakterze prywatnoprawnym - cywilnym, a nie do dziedziny publicznoprawnej, wymagającej oddziaływania administracji publicznej. Wydaje się, że wątpliwości te wciąż pozostają aktualne, aczkolwiek wobec zajęcia stanowiska przez Trybunał Konstytucyjny w formie postanowienia z dnia 13 lutego 2008 roku $^{25}$, w którym odrzucono zarzuty o niekonstytucyjności instytucji nakazu płatniczego, nie są one już tak intensywne.

Wątpliwości te nie są jednak bez znaczenia, albowiem wpłynęły na konstrukcję prawną wystąpienia państwowego inspektora pracy w zakresie wypłacenia mi-

22 T. Niedziński, Ryzyko gospodarcze (finansowe) pracodawcy zwiąane z wykonaniem nakazu płatniczego inspektora pracy, [w:] Wynagrodzenie za prace w warunkach społecznej gospodarki rynkowej i demokracji, red. W. Sanetra, Warszawa 2009, s. 313 n.

23 Ustawa z dnia 21 czerwca 2001 roku o zmianie ustawy o Państwowej Inspekcji Pracy oraz ustawy o postępowaniu egzekucyjnym w administracji, Dz.U. z 2001 r. Nr 76, poz. 809.

24 J. Skoczyński, Kontrowersje dotyczace zmian wprowadzonych w ustawie o Państwowej Inspekcji Pracy, „Praca i Zabezpieczenie Społeczne” 2001, nr 10. Tak też T. Niedziński, op. cit., s. 314 n.

25 SK 5/07, OTK-A 2008/1/19. 
nimalnej stawki godzinowej przysługującej osobom zatrudnionym na podstawie umów zlecenia lub o świadczenie usług względnie dla osób samozatrudnionych. Ustawodawca, ingerując $w$ sferę płacową osób pozostających w stosunkach niepracowniczych, nie zdecydował się bowiem na nakaz płatniczy — jak w wypadku pracowników — lecz posłużył się środkiem niewładczym, jakim jest wystąpienie.

\section{ŚRODKI KONTROLI}

Omawiając problem dotyczący uregulowania wynagrodzenia w kwocie wynikającej z minimalnej stawki godzinowej, zgodnie z przepisami ustawy z dnia 10 października 2002 roku o minimalnym wynagrodzeniu za pracę, należy poczynić kilka uwag wstępnych dotyczących samej instytucji prawnej wystąpienia.

Charakter prawny tego środka prawnego, jakże często stosowanego przez państwowych inspektorów pracy, jest stosunkowo niejednoznaczny. Wskazuje się, że należy on do środków naprawczych ${ }^{26}$, będących elementem postępowania kontrolnego i za takim rozumieniem tej instytucji przemawia wiele okoliczności. Dominujący pogląd o charakterze niewładczym państwowego inspektora pracy znajduje swoje uzasadnienie przede wszystkim w tym, że konstrukcja prawna tego środka prawnego wskazuje na to, że nie jest to decyzja administracyjna, nie podlega też egzekucji. Stanowisko takie jest ugruntowane zarówno w orzecznictwie ${ }^{27}$, jak i w literaturze. Jednocześnie wskazać należy, że ustawodawca przewidział istotne obowiązki podmiotu kontrolowanego w przypadku skierowania do niego wystąpienia. Pierwszy został wyrażony w art. 36 ust. 2 ustawy o PIP, mówiącym,

26 D. Makowski, op. cit., s. 311 n.

27 Zob. na przykład postanowienie Naczelnego Sądu Administracyjnego z dnia 29 maja 2009 roku, sygn. akt I OSK 626/09; „Wystąpienie właściwego organu Państwowej Inspekcji Pracy jako niemające charakteru aktu władczego, a ograniczające się wyłącznie do stwierdzenia faktu naruszenia przepisów prawa pracy i wezwania do jego usunięcia w wyznaczonym terminie, nie jest decyzją administracyjną"; postanowienie Wojewódzkiego Sądu Administracyjnego w Krakowie z dnia 18 maja 2010 roku, sygn. akt III SA/Kr 304/10, LEX nr 784443; „Wystąpienie właściwego organu Państwowej Inspekcji Pracy nie ma charakteru aktu władczego, a ogranicza się wyłącznie do stwierdzenia faktu naruszenia przepisów prawa pracy i wezwania do jego usunięcia w wyznaczonym terminie, nie jest decyzją administracyjną. Wystąpienie Inspektora Pracy ma jedynie charakter zalecenia czy też postulatu pod adresem pracodawcy. Nie ma zaś charakteru aktu władczego"; postanowienie Naczelnego Sądu Administracyjnego z dnia 23 października 2008 roku, sygn. akt I OSK 1029/08, LEX 500994; „1. Wystąpienie inspektora pracy nie rodzi żadnego obowiązku po stronie pracodawcy, ani też nie stwarza żadnego uprawnienia po stronie pracownika. Nie ma ono charakteru władczego i pracodawca nie musi się temu wystąpieniu podporządkować. Jego obowiązkiem jest wyłącznie zawiadomienie inspektora pracy w terminie określonym w wystąpieniu o terminie i sposobie wykonania ujętych w wystąpieniu wniosków. 2. Ustawa z 2007 roku o Państwowej Inspekcji Pracy nie przewiduje żadnej sankcji administracyjnej za nierespektowanie wystąpienia inspektora pracy przez jego adresata. Nie jest też ono poddane egzekucji, więc nie ma wpływu na sytuację prawną strony". 
że podmiot kontrolowany lub organ sprawujący nad nim nadzór, do którego skierowano wystąpienie, jest obowiązany w terminie określonym w wystąpieniu, nie dłuższym niż 30 dni, zawiadomić odpowiedni organ Państwowej Inspekcji Pracy o terminie i sposobie realizacji wniosków pokontrolnych. Wskazana norma prawna obliguje więc pracodawcę lub przedsiębiorcę do powiadomienia państwowego inspektora pracy o tym, w jaki sposób zrealizował wnioski pokontrolne zawarte w wystąpieniu. Skierowany środek prawny wymaga wobec powyższego reakcji od podmiotu zobowiązanego. Dodatkowo należy nadmienić, że położenie nacisku na realizację wystąpienia państwowego inspektora pracy zostało wyrażone wprost w art. $207 \S 2$ pkt 6 k.p. Zgodnie z przytoczonym przepisem pracodawca jest obowiązany chronić zdrowie i życie pracowników przez zapewnienie bezpiecznych i higienicznych warunków pracy przy odpowiednim wykorzystaniu osiągnięć nauki i techniki. W szczególności pracodawca jest obowiązany zapewniać wykonanie nakazów, wystąpień, decyzji i zarządzeń wydawanych przez organy nadzoru nad warunkami pracy. Sposób sformułowania przytoczonej regulacji wyraźnie wskazuje na obowiązek zapewnienia wykonania między innymi wystąpienia, które zostało wymienione obok nakazów i decyzji wydawanych przez organy nadzoru nad warunkami pracy, a takim organem jest państwowy inspektor pracy. Podzielając pogląd o niewładczym charakterze wystąpienia państwowego inspektora pracy, nie sposób jednak nie zauważyć, co trafnie podnosi D. Makow$\mathrm{ski}^{28}$, że ocena charakteru prawnego tej instytucji może nasuwać istotne problemy praktyczne i teoretyczne.

Powracając do rozważań nad wystąpieniem w przedmiocie minimalnej stawki godzinowej dla osób świadczących pracę na podstawie umów cywilnoprawnych, warto podkreślić, że jest to wyjątkowe rozwiązanie prawne. Wyposażenie państwowych inspektorów pracy w tę kompetencję doprowadziło do ingerencji organu administracji publicznej w rozliczenia z tytułu stosunków cywilnoprawnych w zakresie prawa do wynagrodzenia. Przypomnijmy, że zgodnie z art. 11b ustawy o PIP właściwe organy Państwowej Inspekcji Pracy są uprawnione do skierowania wystąpienia lub wydania polecenia w sprawie wypłacenia wynagrodzenia w wysokości wynikającej z wysokości minimalnej stawki godzinowej, zgodnie z przepisami ustawy z dnia 10 października 2002 roku o minimalnym wynagrodzeniu za pracę. Przydanie tego uprawnienia było następstwem zmiany ustawy o PIP przez dodanie organom PIP dodatkowego zadania w postaci kontroli wypłacania wynagrodzenia w wysokości wynikającej z wysokości minimalnej stawki godzinowej, zgodnie z przepisami ustawy z dnia 10 października 2002 roku o minimalnym wynagrodzeniu za pracę. Działanie to jest zrozumiałe i jak się wydaje uzasadnione zarówno prawnie, jak i aksjologicznie. Należy podkreślić, że zgodnie z art. 65 ust. 4 Konstytucji Rzeczypospolitej Polskiej minimalną wysokość wynagrodzenia za pracę lub sposób ustalania tej wysokości określa ustawa, a dodatkowo zgodnie z art. 24

28 D. Makowski, op. cit., s. 318 n. 
Konstytucji praca znajduje się pod ochroną Rzeczypospolitej Polskiej i państwo sprawuje nadzór nad warunkami wykonywania pracy. Wobec tak skonstruowanych norm prawnych rangi konstytucyjnej za uzasadnione należy uznać ustawowe uregulowanie prawa osób fizycznych świadczących pracę na podstawie umów zlecenia oraz umów o świadczenie usług do minimalnego wynagrodzenia za pracę. W literaturze przedmiotu pogląd taki spotyka się ze zrozumieniem i akceptacją ${ }^{29}$. Uzasadnionym rozwiązaniem jest też wskazanie organów Państwowej Inspekcji Pracy jako upoważnionych do wydawania wystąpień w przedmiocie wypłacenia minimalnej stawki godzinowej, co wzmacnia gwarancje ustawowe otrzymania przez osoby fizyczne należnych im świadczeń. Zaznaczyć jednak należy, że zgodnie z literalnym brzmieniem przepisu państwowy inspektor pracy jest uprawniony wyłącznie do skierowania wystąpienia względnie polecenia w sprawie wypłacenia wynagrodzenia w wysokości wynikającej z wysokości minimalnej stawki godzinowej. Oznacza to, że inne kwestie związane z przestrzeganiem ustawy o minimalnym wynagrodzeniu za pracę przysługującemu osobom fizycznym świadczącym pracę na innej podstawie niż stosunek pracy nie mogą być przedmiotem takiego wystąpienia. Jednocześnie zadanie przydane państwowym inspektorom pracy obejmuje kontrolę wypłacania wynagrodzenia w wysokości wynikającej z wysokości minimalnej stawki godzinowej. W praktyce inspektor pracy analizuje dokumenty takie jak umowa, zestawienie przepracowanych godzin, wystawione rachunki i wreszcie dowody wypłat. Badanie tych dokumentów może ujawnić rozmaite nieprawidłowości, na przykład błędne ustalenie stawki godzinowej — zaniżenie, niesporządzanie zestawień przepracowanych godzin, nieterminowe wypłacenie wynagrodzenia czy wreszcie nieścisłości w tych zestawieniach. Wobec tego rodzaju nieprawidłowości zachodzi uzasadniona wątpliwość, czy państwowy inspektor pracy może skierować wystąpienie zalecające usunięcie takich nieprawidłowości, albowiem przedmiotem wystąpienia może być — zgodnie z literalnym brzmieniem przepisu - wyłącznie wypłacenie wynagrodzenia uwzględniającego minimalną stawkę godzinową. Przepis milczy o możliwości skierowania wystąpienia w innym zakresie, na przykład w przedmiocie zobowiązania podmiotu kontrolowanego do ewidencjonowania godzin pracy czy terminowego wypłacania wynagrodzenia. Rozwiązanie takie jest przyczynkiem do problemów w pracy inspektorskiej, ale też wpływa na osłabienie ochronnego charakteru przepisów o minimalnej stawce godzinowej. Wydaje się, że konieczna jest tu pogłębioona refleksja i analiza potrzeb nowelizacji przepisów.

Warto zauważyć, że wobec wcześniej sygnalizowanych wątpliwości w przedmiocie całokształtu regulacji prawnej nakazu płatniczego oddziaływały one na sposób wypracowania przez ustawodawcę środka prawnego, jakim dysponuje pań-

29 Tak też B. Banaszak, op. cit., s. 340 n.; A. Sobczyk, Prawo pracy w świetle Konstytucji $R P$, t. 2. Wybrane problemy i instytucje prawa pracy a konstytucyjne prawa $i$ wolności człowieka, Warszawa 2013, s. 39; E. Maniewska, Zakres uniformizacji ochrony wynagrodzenia za prace w umownych stosunkach zatrudnienia, „Praca i Zabezpieczenie Społeczne” 2019, nr 1, s. 28 n. 
stwowy inspektor pracy w wypadku minimalnej stawki godzinowej przysługującej osobom fizycznym świadczącym pracę w ramach umów cywilnoprawnych. Szczególne zainteresowanie budzą dwie kwestie. Pierwsza związana jest z tym, że w razie naruszeń bezpieczeństwa i higieny pracy ustawodawca przewidział tożsame stosowanie nakazów i zakazów zarówno odnośnie do relacji pracowniczych i niepracowniczych, to jest zarówno do stosunków pracy, jak i do stosunków cywilnoprawnych. Co do wynagrodzeń środki prawne zostały skonstruowane w sposób krańcowo odmienny. Wobec naruszeń praw pracowniczych w zakresie wynagrodzenia za pracę inspektor pracy jest uprawniony do stosowania nakazu, natomiast wobec naruszeń minimalnej stawki godzinowej przysługującej w ramach realizacji zobowiązań o charakterze cywilnoprawnym inspektor może zastosować jedynie wystąpienie, to jest środek niewładczy.

\section{PODSUMOWANIE}

Poczynione uwagi wskazują na dwa zasadnicze obszary aktywności państwowego inspektora pracy, które powinny skłonić regulatora do głębszej refleksji prawnej. Pierwsza z nich dotyczy konieczności uzupełnienia reguł postępowania kontrolnego prowadzonego przez państwowego inspektora pracy w taki sposób, aby uwzględnić postulaty praktyczne i rozwiać wątpliwości prawne, które nie powinny się pojawiać w działalności organu administracji publicznej, zobowiązanego stosować prawo pracy i działać na jego podstawie. Wprowadzenie pewnych rozwiązań prawnych lub ich doprecyzowanie jest niezbędne z punktu widzenia sprawności i skuteczności postępowania państwowego inspektora pracy. Poruszone zagadnienia weryfikacji statusu podmiotu kontrolowanego, wykorzystywania ustaleń dokonywanych w innych kontrolach czy weryfikacji tajemnicy przedsiębiorcy wskazują istotne formalne trudności, z jakimi stykają się w praktyce państwowi inspektorzy pracy. Ich rozwiązanie usprawniłoby przebieg postępowania kontrolnego, a także sprecyzowało obowiązki podmiotu kontrolowanego oraz inspektora pracy, tak aby jakakolwiek ingerencja organu administracji w sferę podmiotu znajdowała wyraźne uzasadnienie ustawowe.

Druga z nich wskazuje na szerszą tezę o stopniowym przewartościowaniu ochrony pracy przez państwo. Opieka Rzeczypospolitej Polskiej nad pracą zarobkową nie koncentruje się już wyłącznie nad formą zatrudnienia pracowniczego, ale również niepracowniczego, co jest wypełnieniem normy konstytucyjnej wyrażonej wprost w art. 24 Konstytucji ${ }^{30}$. Ustawodawca konstytucyjny formułuje w tym artykule nie tylko postulat ochrony państwa nad pracą, lecz także sprawowania

30 Cenne uwagi w tym zakresie formułuje M. Gersdorf, Między ochrona a efektywnościa. Systemowe i terminologiczne aspekty objęcia cywilnoprawnych umów o zatrudnienie ustawodawstwem pracy, „Praca i Zabezpieczenie Społeczne” 2019, nr 1. 
nadzoru nad warunkami wykonywania pracy. Konsekwencją tego uregulowania jest między innymi wzrastająca rola organów Państwowej Inspekcji Pracy — celem realizacji założeń o ochronie i nadzorze nad pracą — wyrażająca się między innymi w sukcesywnym zwiększaniu zadań oraz rozwijaniu funkcji kontrolno-nadzorczej w taki sposób, aby możliwie kompleksowo urzeczywistniać założenia Konsty tucji RP. Owo przewartościowanie prawnej ochrony pracy, nie tylko na stosunki pracownicze, lecz także pozapracownicze, pozwala formułować pewne uwagi o charakterze ogólniejszym - co do zakresu kompetencyjnego państwowych inspektorów pracy. Realizowanie funkcji kontrolno-nadzorczej nad warunkami pracy pracowników oraz niepracowników świadczy w istocie o potrzebie nowego spojrzenia na inspekcję, ale już nie jako na inspekcję pracy, lecz inspekcję zatrudnienia (pracowniczego i niepracowniczego).

Sygnalizowane wcześniej problemy związane z nakazami płatniczymi oraz $\mathrm{w}$ dziedzinie regulowania nieprawidłowości w zakresie bezpieczeństwa i higieny pracy w stosunku do podmiotów niebędących pracodawcami to egzemplifikacja niedoskonałości instytucji prawnych wykorzystywanych w praktyce państwowych inspektorów pracy również wymagająca poszerzonej analizy i wniosków co do ich stosowania. Doniosłość zagadnienia wiąże się powszechnością ich stosowania, lecz także zakresem przedmiotowym, który jest niezwykle istotny w kwestii kompleksowego zapewnienia praworządności w stosunkach prawnych obejmujących świadczenie pracy.

\section{THE IMPLEMENTATION OF CONTROL AND SUPERVISORY MEASURES BY LABOUR INSPECTORS TO ENSURE COMPLIANCE WITH LABOUR PROTECTION PRINCIPLES AND REGULATIONS}

\section{Summary}

The hereby article attempts to present the practical problems faced by national labour inspectors, which they encounter during control and supervision procedures. The significant increase in the number of tasks that the National Labour Inspectorate is responsible for, along with a simultaneous expansion of the scope and intensity of socio-economic relations, gives rise to concerns regarding such proceedings. The primary aim of this publication is to emphasize several important issues related to the control and supervision proceedings conducted by the National Labour Inspectorate. Both the course of the inspections and the legal measures applied by the labour inspectors were analyzed.

Keywords: National Labour Inspectorate, inspection, supervision 


\section{BIBLIOGRAFIA}

Banaszak B., Konstytucja RP. Komentarz, Warszawa 2009.

Baran K.W., [w:] Kodeks pracy. Komentarz, red. K.W. Baran, Warszawa 2012.

Boć J., Prawo administracyjne, Wrocław 1998.

Gersdorf M., Między ochrona a efektywnościa. Systemowe i terminologiczne aspekty objęcia cywilnoprawnych umów o zatrudnienie ustawodawstwem pracy, „Praca i Zabezpieczenie Społeczne" 2019, nr 1.

Gersdorf M., Jagielski J., Rączka K., Komentarz do ustawy o Państwowej Inspekcji Pracy, Warszawa 2008.

Kucharski O., Nakazy płacowe inspektora pracy — geneza i skutki, „Przegląd Prawa Publicznego" 2017, nr 7-8.

Liwo M., Problematyka ryzyka zawodowego w stosunkach pracy i stosunkach stużbowych oraz egzekwowanie jego oceny przez Państwowa Inspekcję Pracy. Studia z zakresu prawa i polityki społecznej, Sosnowiec 2018.

Makowski D., Inspekcja pracy jako instytucja państwowego nadzoru nad przestrzeganiem prawa pracy, Łódź 2017.

Makowski D., [w:] System prawa pracy, t. 8. Prawo rynku pracy, red. M. Włodarczyk, Warszawa 2018.

Maniewska E., Zakres uniformizacji ochrony wynagrodzenia za prace w umownych stosunkach zatrudnienia, „Praca i Zabezpieczenie Społeczne” 2019, nr 1.

Niedziński T., Ryzyko gospodarcze (finansowe) pracodawcy zwiazane z wykonaniem nakazu płatniczego inspektora pracy, [w:] Wynagrodzenie za prace w warunkach spotecznej gospodarki rynkowej i demokracji, red. W. Sanetra, Warszawa 2009.

Nowak M., Wynagrodzenie za prace, Warszawa 2014.

Raczkowski M., Bezpieczne i higieniczne warunki pracy w zatrudnieniu cywilnoprawnym, „Praca i Zabezpieczenie Społeczne" 2019, nr 1.

Skoczyński J., Kontrowersje dotyczace zmian wprowadzonych w ustawie o Państwowej Inspekcji Pracy, „Praca i Zabezpieczenie Społeczne” 2001, nr 10.

Sobczyk A., Państwo zakładów pracy, Warszawa 2017.

Sobczyk A., Prawo pracy w świetle Konstytucji RP, t. 2. Wybrane problemy i instytucje prawa pracy a konstytucyjne prawa $i$ wolności człowieka, Warszawa 2013.

Sobczyk A., Wolność pracy $i$ władza, Warszawa 2015.

Stręk T., Państwowa Inspekcja Pracy, Kraków 1998.

Włodarczyk M., [w:] Prawo pracy i ubezpieczeń społecznych, red. K.W. Baran, Warszawa 2017.

Zieliński T., Goździewicz G., [w:] Kodeks pracy. Komentarz, red. L. Florek, Warszawa 2017.

\section{AKTY PRAWNE}

Ustawa z dnia 26 czerwca 1974 roku Kodeks pracy, tekst jedn. Dz.U. z 2019 r. poz. 1040 z późn. zm. Ustawa z dnia 2 kwietnia 1997 r. Konstytucja Rzeczypospolitej Polskiej, Dz.U. z 1997 r. Nr 78, poz. 78 ze sprost. i zm.

Ustawa z dnia 21 czerwca 2001 roku o zmianie ustawy o Państwowej Inspekcji Pracy oraz ustawy o postępowaniu egzekucyjnym w administracji, Dz.U. z 2001 r. Nr 76, poz. 809.

Ustawa z dnia 10 października 2002 roku o minimalnym wynagrodzeniu za pracę, tekst jedn. Dz.U. z 2018 r., poz. 2177 z późn. zm.

Ustawa $\mathrm{z}$ dnia 20 kwietnia 2004 roku o promocji zatrudnienia i instytucjach rynku pracy, tekst jedn. Dz.U. z 2019 r. poz. 1482. 
Ustawa z dnia 13 kwietnia 2007 roku o Państwowej Inspekcji Pracy, tekst jedn. Dz.U. z 2018 r. poz. $623 \mathrm{z}$ późn. zm.

Ustawa z dnia 10 czerwca 2016 roku o delegowaniu pracowników w ramach świadczenia usług, tekst jedn. Dz.U. z 2018 r. poz. 2206.

Ustawa z dnia 10 stycznia 2018 roku o ograniczeniu handlu w niedzielę i święta oraz w niektóre inne dni, tekst jedn. Dz.U. z 2019 r. poz. 466.

\section{ORZECZNICTWO}

Postanowienie Naczelnego Sądu Administracyjnego z dnia 23 października 2008 roku, sygn. akt I OSK 1029/08, LEX 500994.

Postanowienie Naczelnego Sądu Administracyjnego z dnia 29 maja 2009 roku, sygn. akt I OSK 626/09; http://orzeczenia.nsa.gov.pl/doc/1BF77BB037.

Postanowienie Trybunału Konstytucyjnego z dnia 13 lutego 2008 roku, SK 5/07, OTK-A 2008/1/19.

Postanowienie Wojewódzkiego Sądu Administracyjnego w Krakowie z dnia 18 maja 2010 roku, sygn. akt III SA/Kr 304/10, LEX nr 784443.

Wyrok Naczelnego Sądu Administracyjnego z dnia 4 stycznia 2010 roku, I OSK 791/09, http://orzeczenia.nsa.gov.pl/doc/B18F99E019.

Wyrok Naczelnego Sądu Administracyjnego z dnia 13 lipca 2006 roku, sygn. akt I OSK 1400/05, LEX 2754465. 